\title{
Ovarian-type Tumors (Mullerian Tumors) of the Testis: Clinicopathologic Findings with Recent Advances
}

\author{
Michelle S Lin ${ }^{1}$, Alberto G Ayala ${ }^{1}$, Jae Y Ro
}

Cite this article: Lin MS, Ayala AG, and Ro JY: Ovarian-type tumors (Mullerian tumors) of the testis: Clinicopathologic findings with recent advances. Ann Urol Oncol 2019; 2(1): 36-45. https://doi. org/10.32948/auo.2019.03.07

\begin{abstract}
Ovarian-type epithelial tumors rarely occur in the human testis and paratesticular region. Histologically, these tumors closely resemble their ovarian counterparts and are therefore classified similarly to ovarian epithelial tumors. Most reported ovarian-type tumor cases are serous tumors, but the full spectrum of ovarian neoplasms has been described, including mucinous, endometrioid, clear cell, and Brenner tumors. In this review, we describe the clinical, morphologic, and immunohistochemical features of Mullerian-type epithelial tumors seen in the testis, with an emphasis on comparison with ovarian tumors. We also discuss theories of pathogenesis, considerations in the differential diagnosis, and recent advances in molecular characterization and therapeutic modalities.
\end{abstract}

Key words ovarian-type, Mullerian tumors, serous tumors, clear cell tumors, molecular pathology, targeted treatment

1. Department of Pathology and Genomic Medicine, Houston Methodist Hospital, Weill Cornell Medical College, Houston, TX, USA.

Correspondence: Jae Y. Ro (Department of Pathology and Genomic Medicine, Houston Methodist Hospital, Weill Cornell Medical College, 6565 Fannin Street, M227, Houston, TX 77030, USA; Email: jaero@houstonmethodist.org). 


\section{Introduction}

Ovarian-type epithelial tumors of the testis are very rare, with approximately 100 cases reported in the literature; they are estimated to comprise $5-7 \%$ of non-germ cell testicular tumors [1]. Serous tumors are the most commonly reported tumor type, followed by (in descending order of frequency) mucinous, Brenner, endometrioid, and clear cell tumors [2]. While these tumors are histologically similar to their ovarian namesakes, in some cases, they display distinct clinical associations and immunohistochemical characteristics, and also warrant a unique approach of differential diagnosis. Additionally, because they are so rare, their clinical behavior and overall prognostication compared to ovarian tumors is still not well understood.

Ovarian-type epithelial tumors of the testis most frequently occur in middle-aged males; the mean age of presentation is 50 years [2, 3]. Most tumors present as painless scrotal swelling or palpable scrotal masses, occasionally with associated hydroceles $[3,4]$. The location of the tumor may be either intratesticular or paratesticular, with most paratesticular tumors arising from the tunica vaginalis or the testiculo-epididymal groove [4]. While benign and borderline tumors generally remain localized, malignant tumors are capable of distant metastasis. Commonly reported metastatic sites include lymph nodes, peritoneum, and lungs [5].

The pathogenesis of ovarian-type epithelial tumors of the testis is still not fully understood, and several theories have been proposed for their histologic origin. One of the more widely propounded theories hypothesizes that these tumors arise from Mullerian remnants in the testicular region including the appendix testis, a Mullerian vestige located at the upper pole of the testis. Mullerian epithelial cell rests are also found in the connective tissue between the testis and epididymis and in the spermatic cord $[4,6]$. As many tumors are found in the paratestis, particularly the testiculoepididymal groove, this theory would sufficiently explain the histogenesis of these tumors $[4,6]$. Another possible origin of ovarian-type neoplasms in the testis is via Mullerian metaplasia of the mesothelium lining of the tunica vaginalis, which is consistent with the large proportion of tumors arising from the tunica vaginalis $[4,6]$. As the mesothelium of the ovary is believed to undergo Mullerian metaplasia to differentiate into surface epithelial neoplasms, it is not unreasonable to surmise that the mesothelium of the tunica vaginalis may have a similar capacity. The pathogenesis of intratesticular tumors is less clear, but it has been hypothesized that they develop from entrapped Mullerian or mesothelial inclusions within the testicular parenchyma [4]. Also, specific theories of pathogenesis have been considered for the origin of mucinous and Brenner tumors of the testis. It has been speculated that intratesticular mucinous tumors may be of germ cell origin and develop from one-sided differentiation of teratomas , as mucinous glands have been reported in association with teratomatous tumors. However, the increased age of presentation and the lack of associated intratubular germ cell neoplasia in intratesticular mucinous tumors do not support this theory $[4,7]$. Brenner tumors of the testis have been hypothesized to originate from Walthard cell rests, which in turn arise from urothelial metaplasia of mesothelium. A previous report of a paratesticular Brenner tumor associated with an adenomatoid tumor, which derives from the mesothelium, lends further credence to this theory $[4,8]$.

\section{Ovarian-type tumors of the testis}

\section{Serous tumors}

Serous tumors, comprising benign serous cystadenomas, serous borderline tumors (SBTs), and serous carcinomas, are the most common ovarian-type neoplasm arising in the testicular region, with approximately 60 cases reported in the literature thus far [1, 4-6, 9-61]. The location of the mass may be either intratesticular or paratesticular. Interestingly, a large proportion of serous cystadenomas present in the epididymis, an anatomical distribution not observed in other ovarian-type testicular tumors $[9-11,15]$. Serous cystadenomas usually appear as uniloculated or multiloculated cystic structures surrounded by a thin fibrous capsule containing clear watery fluid $[1,9]$. SBTs may be either solid, cystic, or have components of both, often with papillary excrescences arising from the cyst wall $[4,6]$. In contrast, serous carcinomas are usually solid, ill-defined masses, sometimes with a characteristic gritty quality due to calcifications [3, 5].

Microscopically and immunohistochemically, serous tumors closely resemble their ovarian counterparts (Table 1). Serous cystadenomas are composed of cysts lined by a single layer of cuboidal epithelium with occasional ciliated cells (Figure 1a) $[1,9]$. No atypia or mitosis is present, with papillary projections occasionally observed, but often absent $[1,10]$. In contrast, SBTs usually display papillary structures lined by focally stratified and ciliated cuboidal or columnar epithelium with mild cytologic atypia and occasional psammoma bodies (Figure 1b) $[4,6]$. Serous carcinomas are characterized by stromal invasion, which can be recognized by the presence of desmoplastic response, isolated papillae within artifactual clear spaces, or a solid pattern of neoplastic proliferation (Figure 1c) $[3,36]$. There often is an associated component of SBT, which is rarely observed in ovarian serous carcinomas and only in the context of low-grade serous carcinomas, which comprise only approximately $5 \%$ of ovarian serous cancers [36, 45, 46, 62]. Therefore, this frequent association of borderline differentiation with serous carcinoma in the testis suggests that low-grade carcinomas may make up a much larger proportion - if not virtually all —of the reported cases of serous carcinomas of the testis, a characteristic that is in stark contrast to ovarian carcinomas.

The immunohistochemical profile of testicular serous tumors is virtually indistinguishable from that of ovarian serous tumors $[18,19]$. Most cases are cytokeratin (CK)7-positive, and CK20negative, and also display expression of other epithelial markers, including CAM5.2, AE1/AE3, Ber-EP4, and MOC-31 [6, 36]. In addition, consistent positivity for markers of Mullerian differentiation, such as PAX-8, WT-1, estrogen receptor (ER), progesterone receptor (PR), and CA-125, has been observed[5,18]. Some cases also exhibit reactivity to CA19-9, carcinoembryonic antigen (CEA), S100, and Leu-M1 (CD15) [19, 20]. However, in all cases authors reported negative staining for mesothelial markers (such as calretinin, D2-40, and thrombomodulin), mesonephric markers (such as GATA3 and CD10), and germ cell markers (such as OCT4 and placental alkaline phosphatase [PLAP]) [5, 20]. Ki67 proliferation index has been reported as less than $1 \%$ in serous cystadenoma, $5.5 \%$ in serous borderline tumor, and up to $80-85 \%$ in serous carcinoma $[6,10,38]$.

The main entities considered in the differential diagnosis of serous tumors of the testis include malignant mesothelioma and rete testis adenocarcinoma. Clinically, malignant mesothelioma is more often associated with hydroceles and previous asbestos exposure $[60,63]$. While histologically mesothelioma may display papillary structures lined by cuboidal epithelium similar to serous tumors, typically no stratification, cellular tufting, or ciliation of cells is observed $[6,36]$. Immunohistochemically, mesotheliomas stain positively for calretinin, D2-40, and thrombomodulin, and stain negatively for Leu-M1 (CD15), MOC-31, ER, and PR. Serous tumors display an opposite profile, which renders the differentiation of these two entities fairly straightforward when immunohistochemistry is performed [5, 36, 60]. Adenocarcinomas of the rete testis by definition must be centered at the testicular 


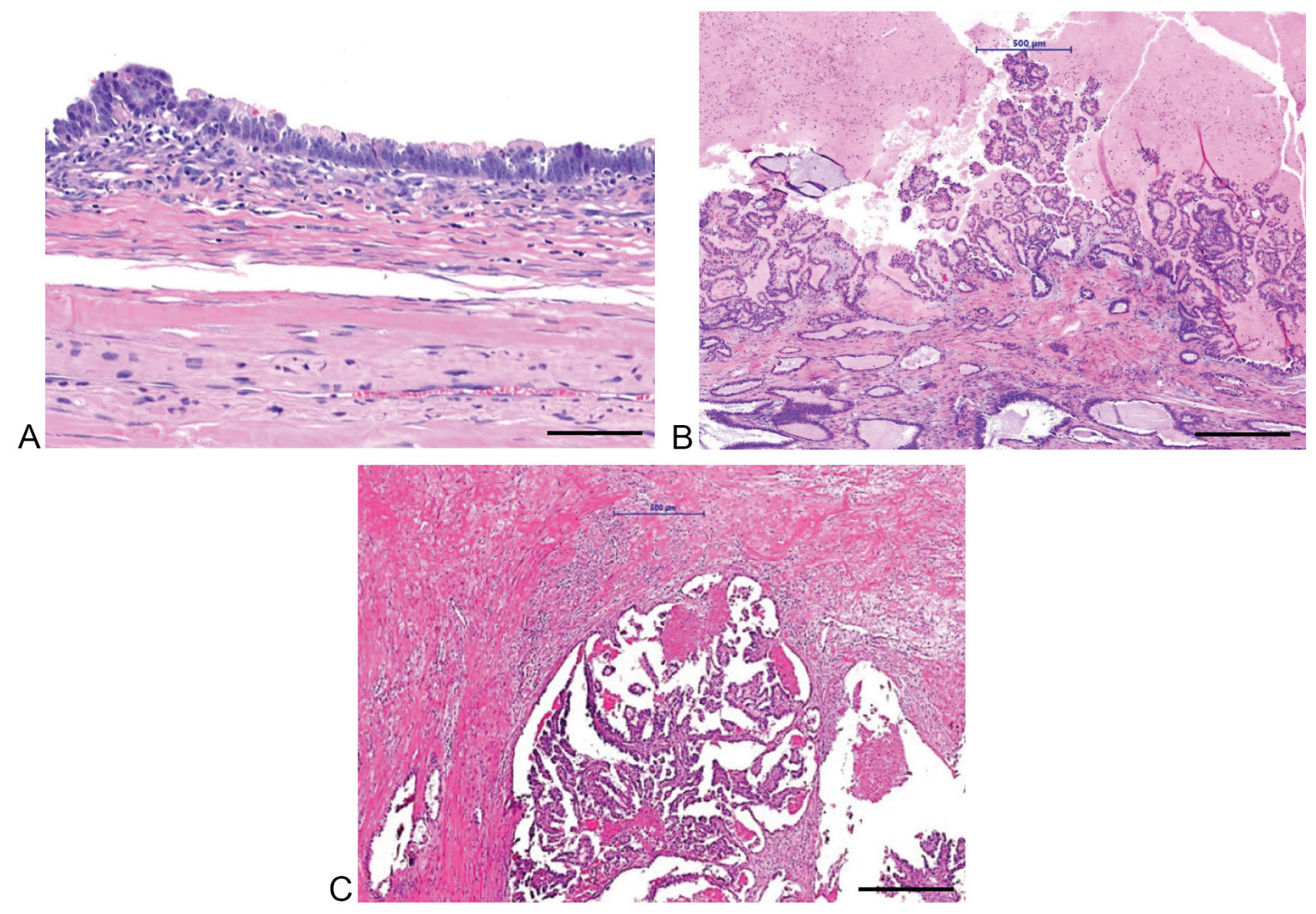

Figure 1. (a) Serous cystadenoma with no cytologic atypia; (b) serous borderline tumor with papillary structure and mild cytologic atypia; and (c) serous carcinoma with stromal invasion and desmoplastic stromal reaction. Scale bar: (a) $=50 \mathrm{um}$; (b) $=100 \mathrm{um}$; (c) $=100 \mathrm{um}$. Courtesy of Drs. Mahul Amin and Jatin Gandhi, University of Tennessee.

hilum, and are additionally are characterized by solid or slit-like tubular architecture. Their composing cells also often display more atypia than those of serous tumors [4, 41]. Immunohistochemical staining for CD10 and GATA3, which are positive in rete testis adenocarcinoma and negative in serous tumors, is a useful characteristic to distinguish these entities [3].

Generally, the clinical course of benign and borderline serous tumors is very favorable, with no reports of recurrence or metastasis following complete orchiectomy. Prognosis for serous carcinoma is more guarded, with reports of metastatic disease to the lymph nodes, peritoneum, lungs, adrenal glands, and leptomeninges [37-40, 45]. Overall, metastasis occurred in $26 \%$ of reported serous carcinoma cases, and death from disease followed in half of those cases.

\section{Mucinous tumors}

Approximately 30 cases of mucinous cystadenoma, mucinous borderline tumors (MBTs), and mucinous adenocarcinoma have been reported in the literature [7, 64-90]. Grossly, the average size of mucinous testicular tumors is $4.2 \mathrm{~cm}$, significantly smaller than ovarian tumors (which frequently exceed $10 \mathrm{~cm}$ ); studies have hypothesized that this difference may result from the more superficial location of testicular tumors, which could cause patients to seek clinical attention at an earlier stage when the tumor is of smaller size [7]. In comparison to ovarian tumors, testicular mucinous cystadenomas and carcinomas are more often unilocular [7, 65]. Histologically, mucinous tumors are characterized by cystic cavities lined by tall columnar bland mucinous epithelium, which may be either endocervical-type or intestinal-type with goblet cells $[7,65]$. MBTs display complex intracystic papillary projections lined by endocervical or intestinal-type epithelium with focal stratification and variable nuclear atypia [7, 64]. Mucinous adenocarcinomas demonstrate features of stromal invasion, such as infiltrating cords within the stroma inciting a desmoplastic response, or a confluent, cribriform glandular architecture composed of cells displaying marked atypia [7, 84]. Interestingly, while ovarian mucinous cystadenomas are almost always composed of endocervical-type epithelium, testicular mucinous cystadenomas more often show intestinal-type epithelium with interspersed goblet cells $[65,74,75,91]$. In addition, testicular tumors often show various trauma-related changes, such as chronic lymphoplasmacytic inflammation, fibrosis, mucin extravasation, cholesterol clefts, calcification, or metaplastic ossification. These features, which are not characteristic of ovarian mucinous tumors, are presumably due to the more superficial location of testicular tumors and resultant trauma $[7,65]$.

The immunohistochemical profile of testicular mucinous tumors differs from that of ovarian tumors in several aspects. The vast majority of testicular mucinous tumors are CK7negative and CK20-positive, regardless of endocervical or intestinal differentiation; a few CK7-positive and CK20-positive examples have been reported $[69,71,75,80,86]$. In contrast, ovarian mucinous tumors are either CK7-positive and CK20positive (if intestinal-type) or CK7-positive and CK20-negative (if endocervical-type) [91, 92]. In addition, testicular tumors consistently display negative expression of markers for Mullerian differentiation, including WT-1, PAX-8, ER, PR, and CA-125. Ovarian cystadenomas, intestinal-type borderline tumors, and carcinomas are also negative for these markers, but endocervicaltype borderline tumors do exhibit positivity $[64,92]$. A few studies analyzing MUC expression in testicular mucinous tumors 

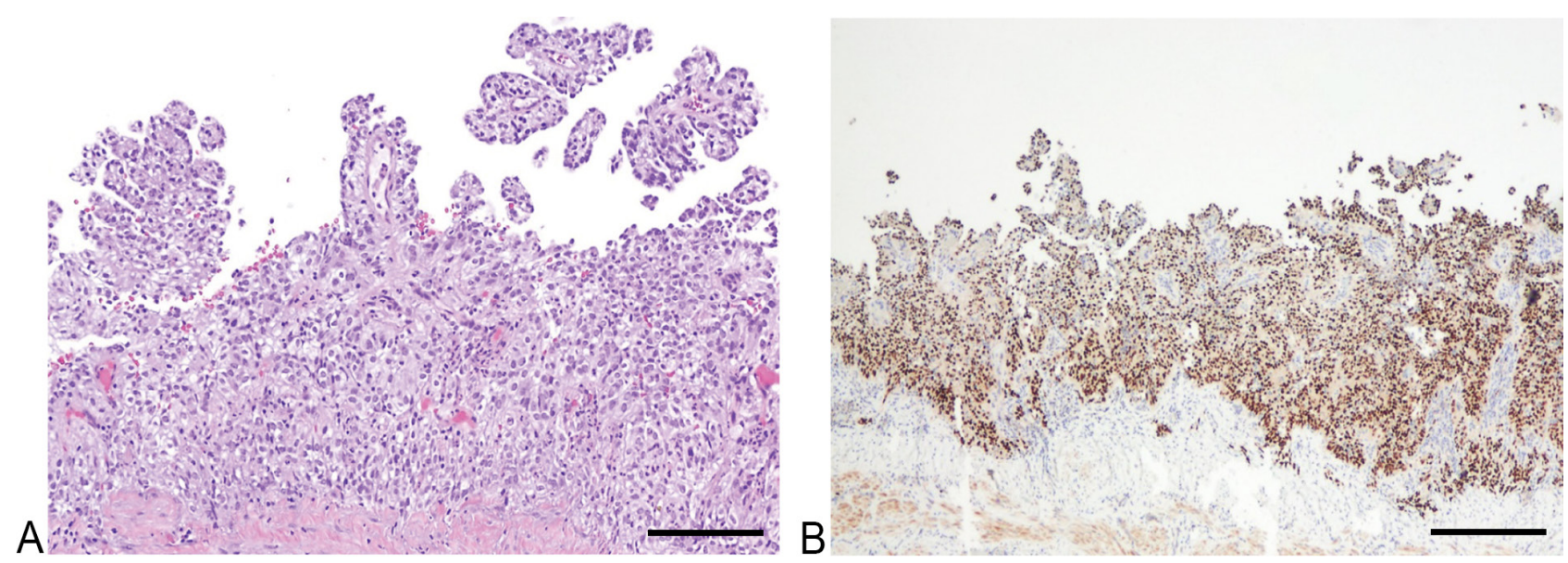

Figure 2. (a) Clear cell adenocarcinoma with papillary structures lined by cuboidal to columnar cells, cytoplasmic clearing, and focal hobnailing; (b) Positive PAX8 immunostain in tumor cells. Scale bar: (a) $=100 \mathrm{um},(\mathrm{b})=100 \mathrm{um}$.

have shown $100 \%$ MUC2 positivity with variable MUC5AC positivity. Conversely, ovarian tumors have exhibited variable MUC2 positivity and $100 \%$ MUC5AC positivity $[67,68,84]$. These stark differences in immunohistochemical staining may reflect a fundamentally different pathogenesis for testicular and ovarian mucinous tumors. Currently, the origin of neither tumor type is well established, with ovarian endocervicaltype mucinous tumors thought to possibly arise from mucinous metaplasia within endometriotic cysts, and intestinal-type tumors possibly arising from mucinous epithelium in the ovarian hilum, Brenner tumors, or mature cystic teratomas [93, 94]. Differential diagnosis of intratesticular mucinous neoplasms can include teratoma, an entity also potentially implicated in the pathogenesis of these tumors, as previously discussed [4, 7]. Generally, presentation at an older age and lack of other teratomatous components or germ cell neoplasia in situ can help distinguish mucinous tumors from conventional teratomas [7]. Another entity that must be considered in the differential diagnosis of testicular mucinous tumors, particularly cystadenocarcinomas, is metastatic mucinous carcinoma, such as those from gastric, colorectal, or pancreatic primary sites $[7,80]$. In addition to the clinical history of a primary tumor at another site, characteristics suggestive of metastasis include bilateral or multifocal involvement, an interstitial pattern of proliferation, and presence of lymphovascular invasion [7]. Another possibility that should be considered in the differential diagnosis is the spread of an appendiceal mucinous tumor along the peritoneal surface to the paratesticular region via an inguinal hernia sac [7]. In comparison to testicular mucinous tumors, appendiceal mucinous tumors typically display more abundant extracellular mucin with a negligible cystic component. However, because appendiceal mucinous tumors display similar CK7 and CK20 expression patterns to testicular mucinous tumors, these markers cannot be used to reliably differentiate between these two neoplasms [7].

Mucinous cystadenomas and MBTs of the testis have a benign clinical course [64]. In contrast, mucinous adenocarcinomas do have significant metastatic potential. Of the nine cases reported in the literature, metastasis was reported in three cases with death occurring in two of those cases [7, 86, 87]. Experience with the clinical course and treatment of testicular mucinous adenocarcinoma is currently very limited [87].

\section{Endometrioid tumors}

Five cases of testicular tumors with endometrioid differentiation have been reported in the literature, including one benign endometriosis-like lesion, one borderline endometrioid tumor, and three malignant endometrioid tumors (two endometrioid cystadenocarcinomas and one endometrioid adenoacanthoma) [4, 95-97]. Interestingly, two cases arose in association with estrogen therapy for prostate cancer, implicating hormonal alterations as a possible factor in the etiology and pathogenesis of these tumors $[4,95]$. Grossly, the tumors had a wide range of appearances and presented as solid or cystic masses. Both intratesticular and paratesticular locations, including one tumor arising from the appendix testis, were reported [4, 95-97]. The tumors also displayed significant variation in histomorphology. The endometriosis-like lesion consisted of well-formed tubular glands lined by a single layer of bland columnar cells, and surrounded by short spindled stromal cells resembling endometrial stroma. The borderline and malignant endometrioid tumors exhibited either papillary architecture with intracystic villous outgrowths or a solid glandular pattern of proliferation, and both were lined by stratified columnar epithelium with variable degrees of atypia [4, 95-97]. The case of endometrioid adenoacanthoma also exhibited areas of squamous differentiation with focal keratinization [4]. Immunohistochemically, studies have demonstrated positivity for CK7, PAX8, WT-1, ER, and PR, similar to the immunostaining profile of ovarian endometrioid tumors [96, 97]. The overall clinical behavior and prognosis of testicular endometrioid tumors, particularly adenocarcinomas, is poorly understood; thus far, no instances of metastasis or death from disease have been reported in cases of these malignant tumors.

\section{Clear cell tumors}

Clear cell Mullerian-type adenocarcinomas of the testis are exceedingly rare, with only three cases reported to date $[48,98$, 99]. Grossly, the tumors appeared as papillary lesions within the testis or arising from the tunica vaginalis. Microscopically, clear cell adenocarcinomas of the testis display similar morphology to their ovarian counterpart, with papillary structures lined by cuboidal to columnar cells with cytoplasmic clearing and focal hobnailing (Figure 2a). One case described occasional psammoma bodies and hyalinized basement membrane-like material within the fibrovascular cores of the papillae, both also characteristic of ovarian tumors [98]. Immunohistochemical studies demonstrated positive CK7 and negative CK20 staining, as well as positive staining for other epithelial markers including EMA and CAM5.2 $[98,99]$. In addition, expression of markers of Mullerian differentiation, including PAX8 (Figure 2b) and CA125, were seen; two cases reported negative staining for ER and PR [98, 99]. The Ki-67 proliferation index is high, reflecting the aggressive nature of this entity $[98,99]$. 
Table 1. Summary of clinical and pathologic features of Mullerian-type testicular tumors.

\begin{tabular}{|c|c|c|c|c|c|}
\hline Items & Serous [1-6, 9-61] & $\begin{array}{l}\text { Mucinous [7, 64- } \\
\text { 90] }\end{array}$ & $\begin{array}{l}\text { Endometrioid [4, } \\
\text { 95-97] }\end{array}$ & $\begin{array}{l}\text { Clear cell }[4,98- \\
\text { 99] }\end{array}$ & $\begin{array}{l}\text { Brenner }[8,100- \\
106]\end{array}$ \\
\hline Age (mean) & 46 & 52 & 72 & 52 & 53 \\
\hline Clinical presentation & $\begin{array}{l}\text { Scrotal swelling, } \\
\text { hydrocele }\end{array}$ & $\begin{array}{l}\text { Scrotal swelling, } \\
\text { sometimes } \\
\text { discomfort }\end{array}$ & Scrotal swelling & $\begin{array}{l}\text { Scrotal swelling, } \\
\text { hydrocele }\end{array}$ & $\begin{array}{l}\text { Scrotal swelling, } \\
\text { sometimes associated } \\
\text { tenderness }\end{array}$ \\
\hline Location & $\begin{array}{l}\text { Intratesticular, } \\
\text { paratesticular } \\
\text { (including } \\
\text { epididymis } \\
\text { in serous } \\
\text { cystadenoma) }\end{array}$ & $\begin{array}{l}\text { Intratesticular, } \\
\text { paratesticular }\end{array}$ & $\begin{array}{l}\text { Intratesticular, } \\
\text { paratesticular } \\
\text { (including } \\
\text { appendix testis) }\end{array}$ & $\begin{array}{l}\text { Intratesticular, } \\
\text { paratesticular } \\
\text { (tunica vaginalis) }\end{array}$ & $\begin{array}{l}\text { Intratesticular, } \\
\text { paratesticular }\end{array}$ \\
\hline Histologic features & $\begin{array}{l}\text { Papillary structures } \\
\text { lined by cuboidal } \\
\text { cells with variable } \\
\text { stratification } \\
\text { atypia, and } \\
\text { mitosis; variable } \\
\text { psammoma bodies }\end{array}$ & $\begin{array}{l}\text { Cystic structures } \\
\text { lined by intestinal } \\
\text { or endocervical- } \\
\text { type epithelium, } \\
\text { sometimes } \\
\text { with intracystic } \\
\text { papillary } \\
\text { projections }\end{array}$ & $\begin{array}{l}\text { Glandular } \\
\text { or villous } \\
\text { architecture, lined } \\
\text { by columnar } \\
\text { epithelium } \\
\text { with variable } \\
\text { stratification and } \\
\text { atypia }\end{array}$ & $\begin{array}{l}\text { Papillary } \\
\text { structures lined } \\
\text { by cuboidal to } \\
\text { columnar cells } \\
\text { with cytoplasmic } \\
\text { clearing and focal } \\
\text { hobnailing }\end{array}$ & $\begin{array}{l}\text { Nests of transitional- } \\
\text { type cells within } \\
\text { fibromatous stroma }\end{array}$ \\
\hline $\begin{array}{l}\text { Immunohistochemical } \\
\text { features }\end{array}$ & $\begin{array}{l}\text { - CK7+ } \\
\text { - PAX8+, WT1+, } \\
\text { - ER+, PR+, } \\
\text { CA125+ }\end{array}$ & $\begin{array}{l}\text { - CK7-/CK20+ } \\
\text { (usually) } \\
\text { - PAX8-, WT1-, } \\
\text { - ER-, PR-, } \\
\text { CA125- } \\
\text { - MUC2+/-, } \\
\text { MUC5AC+ }\end{array}$ & $\begin{array}{l}\text { - CK7+, } \\
\text { - WT1+, ER+, PR+ }\end{array}$ & $\begin{array}{l}\text { - CK7+/CK20- } \\
\text { - CA125+, PAX8+ }\end{array}$ & Not studied \\
\hline $\begin{array}{l}\text { Differences from } \\
\text { ovarian counterpart }\end{array}$ & $\begin{array}{l}\text { Higher occurrence } \\
\text { of serous carcinoma } \\
\text { with SBT in } \\
\text { testicular tumors } \\
{[107]}\end{array}$ & $\begin{array}{l}\text { - Smaller than } \\
\text { ovarian tumors } \\
\text { - Trauma- } \\
\text { associated } \\
\text { changes (fibrosis, } \\
\text { calcification, etc.) } \\
\text { often present [7] } \\
\text { - Different } \\
\text { CK and MUC } \\
\text { immunoprofile }\end{array}$ & $\begin{array}{l}\text { No significant } \\
\text { histological } \\
\text { differences from } \\
\text { ovarian tumors }\end{array}$ & $\begin{array}{l}\text { No significant } \\
\text { histological } \\
\text { differences from } \\
\text { ovarian tumors }\end{array}$ & $\begin{array}{l}\text { No significant } \\
\text { histological } \\
\text { differences from } \\
\text { ovarian tumors }\end{array}$ \\
\hline Treatment & $\begin{array}{l}\text { Orchiectomy (with } \\
\text { possible adjuvant } \\
\text { chemo/radiation for } \\
\text { carcinoma) }\end{array}$ & $\begin{array}{l}\text { Orchiectomy } \\
\text { (with possible } \\
\text { adjuvant } \\
\text { chemotherapy for } \\
\text { carcinoma) }\end{array}$ & Orchiectomy & $\begin{array}{l}\text { Orchiectomy } \\
\text { (possibly } \\
\text { with adjuvant } \\
\text { treatment) }\end{array}$ & Orchiectomy \\
\hline Prognosis & $\begin{array}{l}\text { Good for benign } \\
\text { and borderline } \\
\text { tumors; guarded } \\
\text { for carcinoma }\end{array}$ & $\begin{array}{l}\text { Good for benign } \\
\text { and borderline } \\
\text { tumors; guarded } \\
\text { for carcinoma }\end{array}$ & $\begin{array}{l}\text { Still poorly } \\
\text { understood (no } \\
\text { instances of } \\
\text { metastasis or death } \\
\text { reported) }\end{array}$ & $\begin{array}{l}\text { Guarded (high } \\
\text { incidence of } \\
\text { metastasis) }\end{array}$ & $\begin{array}{l}\text { Excellent for benign } \\
\text { Brenner tumor }\end{array}$ \\
\hline
\end{tabular}

Abbreviations: CK, cytokeratin; ER, estrogen receptor; PR, progesterone receptor; SBTs, serous borderline tumors. 
The differential diagnosis of clear cell adenocarcinoma is broad and includes other entities, which may display clear cell changes with papillary architecture. Malignant mesothelioma of the tunica vaginalis is often characterized by a papillary growth pattern and may uncommonly exhibit cells with cytoplasmic clearing, and thus histologically resembling clear cell adenocarcinoma. However, in regards to immunohistochemistry, mesotheliomas express the mesothelial markers, calretinin and D240, while clear cell carcinoma and other ovarian epithelial-type tumors do not $[98,99]$. Serous carcinomas may also display clear cell change, mimicking clear cell carcinoma, but typically have more psammoma bodies and characteristic stratification with cellular budding and tufting [98]. One final consideration in the differential diagnosis is metastatic carcinoma, especially renal cell carcinoma; usually, clinical history and imaging can facilitate exclusion of possible metastasis [98].

The prognosis of clear cell adenocarcinoma is guarded. Two of the reported cases presented with metastatic disease, including pulmonary deposits and lymphadenopathy $[48,98]$. One patient underwent radiation with reported resolution of symptoms at five months, while the other patient had a more aggressive disease course and died two weeks following orchiectomy [48, 98].

\section{Brenner tumors}

Eight cases of Brenner tumors of the testis have been described in the literature $[8,100-106]$. Grossly, these tumors usually appear as cystic masses, which may be situated within the testis or in the paratesticular region. Microscopically, Brenner tumors of the testis are essentially identical to their ovarian counterparts; typically, a biphasic architecture composed of nests of transitional-type cells with elongated grooved nuclei within a fibromatous stroma is seen [8]. One case described a malignant component characterized by areas of urothelial and squamous carcinoma with invasion into and involvement of the epididymis and vas deferens. Another case described an associated adenomatoid tumor, which, as discussed previously, provides evidence of a possible mesothelial origin for testicular Brenner tumors, since adenomatoid tumors also arise from mesothelium [101, 106]. Generally, the prognosis of benign Brenner tumors is excellent, as with ovarian Brenner tumors [8]. The only reported case of malignant Brenner tumor reported metastasis to the para-aortic lymph nodes, with the patient still alive two years after diagnosis following intensive chemotherapy [106].

\section{Prospective}

Recent studies on ovarian-type testicular tumors have focused on molecular characterization and the role of adjuvant therapy in treatment, particularly for serous tumors. In the past few years, several studies demonstrated the presence of the BRAF V600E mutation in SBTs of the testis, also seen in SBTs and lowgrade serous carcinomas of the ovary [18, 28, 107]. This finding provides a clear genetic association between testicular and ovarian low-grade serous neoplasms and suggests similar pathogenesis to ovarian SBTs and low-grade serous carcinomas believed to derive from Mullerian metaplasia of surface epithelium [28]. However, while the BRAF V600E mutation has been shown in testicular SBTs, it has not been extensively studied for testicular serous carcinomas. It is possible that the BRAF V600E mutation may be present in low-grade serous carcinomas, but not highgrade tumors, as their ovarian counterparts have a completely different proposed histogenesis (from fallopian tube epithelium) and molecular alterations (TP53 mutations) $[28,107]$. In fact, an extensive literature review showed that stratification of testicular serous carcinomas into low- and high-grade tumors is not an established practice as it is for ovarian serous carcinomas [28, 107]. Given the vastly different origins of these tumors and the aforementioned suggestion that low-grade serous carcinomas may constitute a much higher proportion of serous cancers in the testis compared to the ovary, further molecular analysis of testicular serous carcinomas is warranted. Further analysis would not only facilitate sub-classification into low- and high-grade groups but also help elucidate fundamental similarities and differences between the nature of ovarian and testicular serous tumors. Because very few cases of other types of Mullerian tumors in the testis have been described, molecular characterization of such tumors has not yet been reported.

As Mullerian-type neoplasms in the testes rarely occur, experience with various treatment modalities, especially for malignancies, is still very limited. The most widely used practice for benign, borderline, and malignant tumors includes radical orchiectomy. However, Grisantiet al. recently reported a case of SBT managed only with resection of the mass and no orchiectomy, with no evidence of disease after eight years of follow-up [30]. This successful outcome with a conservative treatment approach highlights the indolent nature of testicular SBTs (indeed, no instances of metastasis have been reported in the literature) and suggests that orchiectomy may not always be necessary for the management of these tumors. The role of adjuvant chemotherapy following surgery has been controversial for malignant ovariantype tumors of the testis, with several past studies documenting resistance of serous carcinoma to chemotherapy and radiation $[5,45]$. However, a few recently reported cases of serous and mucinous carcinomas have shown response to a carboplatin and paclitaxel-based regimen (a first-line chemotherapeutic regimen for ovarian serous carcinomas), thus demonstrating that these modalities of treatment have similar efficacies against testicular and ovarian tumors $[43,44]$. While targeted treatment of ovariantype testicular tumors has not been reported in the literature, studies assessing the efficacy of various targeted therapies in ovarian cancer patients have shown promising results [108, 109]. Nonetheless, future studies incorporating guidelines used in the treatment of ovarian carcinomas will help establish the optimal therapy for testicular ovarian-type carcinomas, and shed more light on the biological behavior of these heretofore relatively obscure entities.

\section{Acknowledgments}

The authors thank Drs. Helen Chifotides(hchifotides@, houstonmethodist.org) and Sasha M. Pejerrey(spejerrey@ houstonmethodist.org) for their excellent editorial assistance.

\section{Funding}

This research did not receive any specific grant from funding agencies in the public, commercial, or not-for-profit sectors.

\section{Ethical policy}

No research involving experimentation on human or animal subjects was conducted.

\section{Author contributions}

MSL performed the literature review and wrote the manuscript. AGA reviewed and approved the manuscript. JYR conceived the project and directed the organization and content of the manuscript. All authors read and approved the final manuscript.

\section{Competing interests}


All authors declare no competing interests.

\section{References}

1. Talmon GA, Johannson SL: Serous cystadenoma of the epididymis. Urology 2007, 70(2): 372-377.

2. Henley JD, Ferry J, Ulbright TM: Miscellaneous rare paratesticular tumors. Semin Diagn Pathol 2000, 17(4): 319-339.

3. Amin MB: Selected other problematic testicular and paratesticular lesions: rete testis neoplasms and pseudotumors, mesothelial lesions and secondary tumors. Modern Pathol 2005, 18(S2): S131.

4. Young RH, Scully RE: Testicular and paratesticular tumors and tumor-like lesions of ovarian common epithelial and mullerian types: a report of four cases and review of the literature. Am J Clin Pathol 1986, 86(2): 146-152.

5. Pease GF, Chou PM: Serous carcinoma of the testicle and the paratesticular tissue: case report and literature review. Urology 2018 111: $183-185$.

6. McClure RF, Keeney GL, Sebo TJ, Cheville JC: Serous borderline tumor of the paratestis: a report of seven cases. Am J Surg Pathol 2001, 25(3): 373-378.

7. Ulbright TM, Young RH: Primary mucinous tumors of the testis and paratestis: a report of nine cases. Am J Surg Pathol 2003, 27(9): 1221-1228.

8. Quan J, Jin L, Hu J, He T, Pan X, Ding Y, Peng J, Chen Z, Yang S, Mao X, Lai Y: Brenner tumor of the testis: a case report and review of the literature. Mol Clin Oncol 2017, 6(1): 119-121.

9. Fernández-Aceñero MJ, Renedo G, Fortes J, Manzarbeitia F:Nonpapillary serous cystadenoma of the epididymis: report of 2 cases of a rare entity. Urology 2010, 75(3): 563-565.

10. Pich A, Galliano D: Pure (non-papillary) serous cystadenoma of the epididymis: a histologic and immunohistochemical study. Pathol Res Pract 2005, 201(1): 65-69.

11. Klimis T, Vlahos P, Kokotas N: Serous cystadenoma of the epididymis of common epithelial ovarian type: case report with an immunohistochemical study. J BUON 2006, 11(2): 237-240.

12. Kosmehl H, Langbein L, Kiss F:Papillary serous cystadenoma of the testis. Int Urol Nephrol 1989, 21(2): 169-174.

13. Olla L, Di NN, Puliga G, Tolu GA: Intraparenchymal serous papillary cystadenoma of the testis: a case report. Pathologica 2013, 105(1): 15-17.

14. Chaubey S, Lloyd DM: Papillary cystadenoma of testis. J Urology 2001, 165(2): 535.

15. Abdull-Gaffar B, Al-Hasani S, El-Fayomy A:Multiple bilateral nonpapillary serous cystadenoma of the epididymis. Urology 2013, 82(3): 24-25.

16. Kumar PV, Shirazi M, Salehi M: A Diagnostic Pitfall of Fine Needle Aspiration Cytology in Testicular Papillary Serous Cyst Adenoma. Acta Cytol 2009, 53(4): 467-470.

17. Meister P, Keiditsch E, Stampfl B: Intratesticular papillary cystadenoma. A rare analogue of serous papillary cystadenoma of the ovary. Der Pathologe 1990, 11(3): 183-187.

18. Bürger T, Schildhaus HU, Inniger R, Hansen J, Mayer P, Schweyer S, Radzun HJ, Ströbel P, Bremmer F: Ovarian-type epithelial tumours of the testis: immunohistochemical and molecular analysis of two serous borderline tumours of the testis. Diagn Pathol 2015, 10: 118.

19. Carano KS, Soslow RA: Immunophenotypic analysis of ovarian and testicular Müllerian papillary serous tumors. Modern Pathol 1997, 10(5): 414-420.

20. Maruyama H, Ohyama N, Hosokawa Y, Momose H, Yamada K, Tsutsumi M, Kuniyasu H, Enomoto Y, Uematsu K, Konishi Y: Serous borderline tumor of the paratestis. Pathol Int 2008, 58(5): 311-316.

21. McCluggage WG, Shah V, Nott C, Clements B, Wilson B, Hill CM: Cystadenoma of spermatic cord resembling ovarian serous epithelial tumour of low malignant potential: immunohistochemical study suggesting Müllerian differentiation. Histopathology 1996, 28(1): $77-80$.

22. Cohen MC, Shawis R, Evans C: Para testicular müllerian-type papillary serous tumor in a child. Pediatr Devel Pathol 2009, 12(4): 297-300.

23. Ibrahim AS, Li C, Al-Jafari MS: Borderline serous papillary tumour of the testis: a case report and review of the literature. Anticancer Res 2012, 32(11): 5011-5013.

24. Klaassen Z, Fox PJ, McLees L, Zheng M, Sharma S, Donohoe JM, Neal Jr DE: A paratesticular serous borderline tumor in a pediatric patient with proteus syndrome. Urology 2015, 86(6): 1218-1221.

25. Patel M, Dudiak C, Turk T, Picken M: A unique case of a serous borderline tumor of the paratestis. Urol Ann 2015, 7(3): 380-382.

26. Raza SA, Iturregui JM, Daley SM, Steinway ML: Paratesticular serous papillary borderline tumor. J Urology 2014, 192(2): 552-553.

27. Hsieh A, Miller M, He W, Shin D: Serous Borderline Tumor of the Testis and Associated Magnetic Resonance Imaging Findings. Urol Case Rep 2017, 14: 30-32.

28. Cundell D, Pawade J, Sohail M, Melegh Z: The V600E BRAF mutation in a borderline serous tumour of the testis is genotypic evidence of similarity with its phenotypic ovarian counterpart. Histopathology 2015, 67(1): 142-144.

29. Sumrall A, Puneky L, Brown A, Thigpen JT: Ovarian Cancer in a Man? Clin Ovarian Cancer 2009, 2(1): 57-59.

30. Grisanti SC, Martini A, Bigazzi B, Raspollini MR, Delle Rose A, Villari D, Nicita G: Conservative treatment of serous borderline paratesticular tumor in a pediatric patient. Urology 2016, 89: 123125.

31. Albino G, Nenna R, Inchingolo CD, Marucco EC: Hydrocele with surprise. Case report and review of literature. Arch Ital Urol Nefrol Androl 2010, 82(4): 287-290.

32. Shadhu K, Ramlagun D, Zhu K, Zhang Y, Chen C, XiD, Zhu J, Miao C, Wang Y, Qin C: Testis Tumor of Ovarian Epithelial Type: A Rare Case. Urology 2018, 115: 9-10.

33. Romero-Tejada JC, Fernandez-Arjona M, Gomez-Sancha F, Peinado-Ibarra F, Fraga-Fernandez J: Intratesticular serous papillary cystadenoma: a tumour managed by partial orchiectomy. Br J Urol 1998, 82(4): 606-607.

34. Brito CG, Bloch T, Foster RS, Bihrle R: Testicular papillary cystadenomatous tumor of low malignant potential: a case report and discussion of the literature. J Urology 1988, 139(2): 378-379.

35. Abdullah LS, Gupta R, Arnst A: Intratesticular borderline serous tumor. Int J Urol 2006, 13(12): 1536-1538.

36. Jones M, Young RH, Srigley JR, Scully RE: Paratesticular serous papillary carcinoma. A report of six cases. Am J Surg Pathol 1995, 19(12): 1359-1366.

37. Blumberg HM, Hendrix LE: Serous papillary adenocarcinoma of the tunica vaginalis of the testis with metastasis. Cancer 1991, 67(5): $1450-1453$.

38. Aravind S, Nayanar SK, Varadharajaperumal R, Satheeshbabu TV, Balasubramanian S: High grade serous cystadenocarcinoma of testis-case report of a rare ovarian epithelial type tumour. J Clin Diagn Res 2017, 11(6): 13-15.

39. Filatenkov A, Strickland A, Karpowicz M, Francis F: Lowgrade serous carcinoma (Mullerian/ovarian type) of the paratestis presenting as diffuse metastatic disease of unknown origin: Case report of an uncommon tumor with an unusual presentation. Hum Pathol Case Rep 2018, 11: 47-50.

40. Monteiro LM, Brandão LF, Cardili L, Sadi MV: High-grade metastatic paratesticular cystadenocarcinoma. Urol Case Rep 2018, 17: 62-64.

41. Yeh CH, Hsieh PP, Lin SJ, Hong YC, Tsai TH, Yu LH, Yu MS: Testicular serous carcinoma of ovarian epithelial type. J Cancer Res Pract 2017, 4(2): 76-79.

42. GuarchR., Rivas A., Puras A., Pesce C: Papillary serous carcinoma 
of ovarian type of the testis with borderline differentiation. Histopathology 2005, 46(5): 587-599.

43. Vaughn DJ, Rizzo TA, Malkowicz SB: Chemosensitivity of malignant ovarian-type surface epithelial tumor of testis. Urology 2005, 66(3): 658 .

44. Lifton J, Ghodoussipour S, Xiao GQ, Dorff T, Loh-Doyle J, Boyd SD: Paratesticular Serous Papillary Carcinoma of High Grade and Malignant Potential: A Rare Case with a Role for Adjuvant Therapy. Cureus 2018, 10(2): e2188.

45. Ma YT, Chaudhri S, Cullen MH: Metastatic serous carcinoma of the testis: a case report and review of the literature. Case Rep Oncol 2011, 4(1): 246-249.

46. Remmele W, KaiserlingE, Zerban U, Hildebrand U, Bennek M, Jacobi-Nolde P, Pinkenburg FA:Serous papillary cystic tumor of borderline malignancy with focal carcinoma arising in testis: case report with immunohistochemical and ultrastructural observations. Hum Pathol 1992, 23(1): 75-79.

47. Herschman BR, Ross MM: Papillary cystadenoma within the testis. Am J Clin Pathol 1974, 61(5): 724-729.

48. Teilum G. Special tumors of the ovary and testis. In: Teilum G, editor. Comparative Pathology and Histological Identification. Philadelphia: JB Lippincott; 1976. p466-469.

49. Axiotis CA: Intratesticular serous papillary cystadenoma of low malignant potential: an ultrastructural and immunohistochemical study suggesting müllerian differentiation. Am J Surg Pathol 1988 , 12(1): 56-63.

50. Walker AN, Mills SE, Jones PF, Stanley CM III: Borderline serous cystadenoma of the tunica vaginalis testis. Surg Pathol 1988, 1 431-436.

51. De NictolisMD, Tommasoni S, Fabris G, Prat J: Intratesticular serous cystadenoma of borderline malignancy. A pathological, histochemical, and DNA content study of a case with long-term follow up. Virchows Arch A Pathol Anat 1993, 423(3): 221-225.

52. Dupré F, Zachar D, Choquenet C, Clément N, Mainguene C, Vieillefond A: Apropos of 1 case of paratesticular papillary serous cystadenocarcinoma. Ann Pathol 2001, 21(1): 63-66.

53. Becerra P, Isaac MA, Márquez B, Garcia-Puche JL, Zuluaga A, Nogales FF: Papillary serous carcinoma of the tunica vaginalis testis. Pathol Res Pract 2000, 196(11): 781-782.

54. Sugishita K, Kashiwag, A, Nagamori S, Yamashiro K, Sato N: Serous papillary adenocarcinoma of the tunica vaginalis of the testis: a case report. Nihon Hinyokika Gakkai Zasshi 2004, 95(3): 626-629.

55. Kurian RR, Prema NS,Belthazar A: Paratesticular papillary serous cystadenocarcinoma-a case report. Indian J Pathol Microbiol 2006, 49(1): 36-37.

56. Mermershtain W, Vardi N, Gusakova I, Klein J: Serous papillary adenocarcinoma of the rete testis: unusual ultrasonography and pathological findings. J Cancer Res Ther 2007, 3(1): 37-39.

57. Delahunt B, Nacey JN: Ovarian-type papillary serous cystadenocarcinoma of the testis. Br J Urol 1996, 77(1): 156-157.

58. Leonardo C, Franco G, Michetti M, De Nunzio C, Zampelli A, De Dominicis C: A rare case of serous papillary cystadenocarcinoma of the testis. J Androl 2010, 31(5): 434-436.

59. Geramizadeh B, Farzaneh MR, Pakbaz S, Zeighami S: Testicular papillary serous cystadenocarcinoma: a rare case report and review of the literature. Rare Tumors 2011, 3(4): 139-140.

60. Anchala PR, Dhir R, Parwani AV, Zynger DL: Immunohistochemical profile of paratesticular serous papillary adenocarcinoma and tunica vaginalis facilitates distinction from malignant mesothelioma. Int $\mathrm{J}$ Surg Pathol 2011, 19(5): 692-698.

61. Narang V, Sood N, Garg B,Aulakh BS: Paratesticular papillary serous cystadenocarcinoma: a rare entity in Indian population. Indian J Pathol Microbiol 2014, 57(4): 614-616.

62. Plaxe SC: Epidemiology of low-grade serous ovarian cancer. Am J Obstet Gynecol 2008, 198(4): 459 e451-458; discussion 459 e458459.
63. Trenti E, Palermo SM, D'Elia C, Comploj E, Pycha A, Carella R, Pycha A: Malignant mesothelioma of tunica vaginalis testis: Report of a very rare case with review of the literature. Arch Ital Urol Androl 2018, 90(3): 212-214.

64. Elliott JE, Klein JR, Drachenberg DE: Primary testicular mucinous neoplasms: case report and literature review. Can Urol Assoc J 2010, 4(4): E112-E115.

65. Kim G, Kwon D, Na HY, Kim S, Moon KC: Mucinous cystadenoma of the testis: a case report with immunohistochemical findings. J Pathol Transl Med 2017, 51(2): 180-184.

66. Shimbo M, Araki K, Kaibuchi T, Kuramochi H, Mori I: Mucinous cystadenoma of the testis. J Urology 2004, 172(1): 146-147.

67. Nokubi M, Kawai T, Mitsu S, Ishikawa S, Morinaga S: Mucinous cystadenoma of the testis. Pathol Int 2002, 52(10): 648-652.

68. Naito S, Yamazumi K, Yakata Y, Shono T, Hakariya H, Nakayama T, Nakashima M, Sekine I: Immunohistochemical examination of mucinous cystadenoma of the testis. Pathol Int 2004, 54(5): 355-359.

69. Alasio TM, Borin J, Taylor K, Bar-Chama N, Unger PD:Intratesticular mucinous cystadenoma: immunohistochemical comparison with ovarian and colonic tissue. Arch Pathol Lab Med 2005, 129(3): 399-402.

70. Kellert E: An ovarian type pseudomucinous cystadenoma in the scrotum. Cancer 1959, 12(1): 187-190.

71. Uschuplich V, Hilsenbeck JR, Velasco CR: Paratesticular mucinous cystadenoma arising from an oviduct-like mullerian remnant: a case report and review of the literature. Arch Pathol Lab Med 2006, 130(11): 1715-1717.

72. Gao L, Li J, Wan Y, Han P: Primary mucinous cystadenoma originating from testis: a case report and review of literature. Int $\mathrm{J}$ ClinExp Med 2017, 10(2): 4008-4010.

73. de Lima Jr MM, de Lima MM, Granja F: Primary testicular mucinous cystadenoma: Case report and literature review. Can Urol Assoc J 2015, 9(11-12): E814-E816.

74. Kim JY, Lee YT, Kang HJ, Lee CH: Primary mucinous cystadenoma of the spermatic cord within the inguinal canal. Diagn Pathol 2012, 7(1): 139 .

75. Iuga AC, Mull J, Batra R, Miller W: Mucinous cystadenocarcinoma of the testis: A case report. Hum Pathol 2011, 42(9): 1343-1347.

76. Mesia L, Georgsson S, Zuretti A: Ossified intratesticular mucinous tumour. Arch Pathol Lab Med 1999, 123(3): 244-246.

77. Mai KT, Carlier M, Lajeunesse C: Paratesticular composite tumour of epididymal-like and mucinous cells of low malignant potential. Histopathology 1998, 33(2): 193-194.

78. Mukerjee MG, Norris M, Strum DP, Mittemeyer BT, Borski AA: Mucinous adenoid tumour of the paratesticular tissue. J Urology 1976, 115(4): 472-473.

79. Pratap K, Perera M, Malczewski F, Esler R:Borderline Mucinous Testicular Tumour: Diagnostic and Management difficulties. BMJ Case Rep 2018, 2018: bcr-2017-223787.

80. Menon S, Ahmed S, Desai S: Primary borderline mucinous neoplasm of the testis: A case report and literature review. Indian J Urol 2012, 28(2): 224-226.

81. Andrejevic M, Jotanovic J, Rom AD, Cumic M, Micev M: Primary borderline mucinous tumour of the testis: A case report. Virchows Arch 2015, 467: 269.

82. Funada S, Yoshida T, Ito M, Kono F, Segawa T: Primary borderline mucinous tumors of the testis: a case report and literature review. Case Rep Oncol Med 2015, 2015: 863745.

83. Nistal M, Revestido R, Paniagua R:Bilateral mucinous cystadenocarcinoma of the testis and epididymis. Arch Pathol Lab Med 1992, 116(12): 1360-1363.

84. Teo CH, Chua WJ, Consigliere DT, Raju GC: Primary intratesticular mucinous cystadenocarcinoma. Pathology 2005, 37(1): 92-94.

85. Elbadawi A, Batchvarov MM, Linke CA: Intratesticular papillary mucinous cystadenocarcinoma. Urology 1979, 14(3): 280-284.

86. Maruschke M, Schmidt W, Casper J, Hakenberg OW: Ovarian type 
surface epithelial carcinoma of the testis with delayed metastatic spread. Urol Int 2008, 81(1): 119-121.

87. Azuma T, Matayoshi Y, Nagase Y: Primary mucinous adenocarcinoma of the testis. Case Rep Med 2012, 2012: 685946.

88. Di Franco CA, Porru D, Viglio A, Paulli M, Rovereto B: Primary paratesticular mucinous "ovarian-type" adenocarcinoma: a rare case of scrotal tumor in a patient with history of bilateral cryptorchidism. World J Nephrol Urol 2015, 4(4): 260-263.

89. Rao NB, Sudhakar G, Swathi VR, Kumar AH: Mucinous adenocarcinoma of testis-a rare case report. J Evol Med Dent Sci 2015, 4(75): 13144-13148.

90. Celdran JO, Rodriguez CS, Valverde FM, Compiano LO: Primary mucinous cystadenocarcinoma of the testis: an extremely rare ovarian-type surface epithelial carcinoma. J Cancer Res Ther 2015, 11(3): 647.

91. Hart WR: Mucinous tumors of the ovary: a review. Int J Gynecol Pathol 2005, 24(1): 4-25.

92. Vang R, Gown AM, Barry TS, Wheeler DT, Ronnett BM: Ovarian atypical proliferative (borderline) mucinous tumors: gastrointestinal and seromucinous (endocervical-like) types are immunophenotypically distinctive. Int J Gynecol Pathol 2005, 24(1): $4-25$.

93. Shiohara S, Shiozawa T, Shimizu M, Toki T, Ishii K, Nikaido T, Fujii $\mathrm{S}$ : Histochemical analysis of estrogen and progesterone receptors and gastrictype mucin in mucinous ovarian tumors with reference to their pathogenesis. Cancer 199, 80(5): 908-916.

94. Seidman JD, Khedmati F: Exploring the histogenesis of ovarian mucinous and transitional cell (Brenner) neoplasms and their relationship with Walthard cell nests: a study of 120 tumors. Arch Pathol Lab Med 2008, 132(11): 1753-1760.

95. Kernohan NM, Coutts AG, Best PV: Cystadenocarcinoma of the appendix testis. Histopathology 1990, 17(2): 147-154.

96. Numakura K, Tsuchiya N, Tsuruta H, Obara T, Saito M, Inoue T, Narita S, Horikawa Y, Satoh S, Nanjyo H, Habuchi T:A case of intratesticular endometrioid papillary cystadenocarcinoma. Jpn J Clin Oncol 2011, 41(5): 674-676.

97. Obliers A, Hinz R, Erbersdobler A: Endometrioid borderline tumor of the testis. A rare cause of cystic neoplasia. Der Pathologe2014, 35(5): 504-507.

98. Tulunay Ö, Göğüş Ç, Baltacı S, Bulut Ş: Clear cell adenocarcinoma of the tunica vaginalis of the testis with an adjacent uteruslike tissue. Pathol Int 2004, 54(8): 641-647.

99. Lin MS, Awalt HL, Ayala AG, Ro JY: Clear cell carcinoma of testis: A review. Ann Diagn Pathol 2019, 40:26-29.

100. Goldman RL:A Brenner tumor of the testis. Cancer 1970, 26(4): 853-856.

101. Nogales FF Jr, Matilla A, Ortega I and Alvarez T: Mixed Brenner and adenomatoid tumor of the testis: An ultrastructural study and histogenetic considerations. Cancer 1979, 43(2): 539-543.

102. Ross L: Paratesticular Brenner-like tumor. Cancer1968, 21(4): 722-6.

103. Vechinski TO, Jaeschke WH and Vermund H: Testicular tumors. An analysis of 112 consecutive cases. Am J Roentgenol Radium Ther Nucl Med 1965, 95(2): 494-514.

104. Jones S, Cord J: Incidental Brenner Tumor in a Testis. Med Res Arch 2018, 6(5): 1-5.

105. Brennan MK, Srigley JR: Brenner tumor of the testis: case report and review of other intrascrotal examples. J Urol Pathol 1999, 10(3): 219-228.

106. Caccamo D, Socias M, Truchet C: Malignant Brenner tumor of the testis and epididymis. Arch Pathol Lab Med 1991, 115(5): 524-527.

107. Gwiti P, Vereczkey I, Cundell D, Aslam S, Clench T, Csernák E, Götzer K, Braybrooke J, Sohail M, Melegh Z: The mutational frequency of braf and kras in low-grade serous testicular neoplasms - a case series. Histopathology 2017, 71(5): 686-692.

108. Coward JI, Middleton K, Murphy F: New perspectives on targeted therapy in ovarian cancer. Int J Women's Health 2015, 7: 189-203.
109. Gasparri ML, Bardhi E, Ruscito I, Papadia A, Farooqi AA, Marchetti C, Bogani G, Ceccacci I, Mueller MD, Panici PB: PI3K/ AKT/mTOR pathway in ovarian cancer treatment: are we on the right track? Geburtshilfe Frauenheilkunde 2017, 77(10): 1095-1103. 